\title{
BAKTI SOSIAL SEBAGAI UPAYA PENCEGAHAN PENYEBARAN VIRUS COVID-19 DALAM MEMASUKI FASE NEW NORMAL DI KELURAHAN LOA BUAH
}

\author{
Kornelia Mina ${ }^{1}$, Imelda Feneranda Seravia Tambi ${ }^{2}$, dan Roberta Yutri ${ }^{3}$ \\ Program Studi DIII Keperawatan, STIKES Dirgahayu Samarinda \\ Jl. Pasundan No.21 Kelurahan Jawa, Kecamatan Samarinda Ulu, Kota Samarinda 75122 \\ e-mail: korneliamina@yahoo.com
}

\begin{abstract}
ABSTRAK
Penyebaran virus covid 19 pada tahun 2020 menjadi tantangan khusus bagi seluruh Negara dan berbagai aspek kehidupan. Peningkatan jumlah kasus yang terkofirmasi memberikan perhatian khusus bagi persiapan dan pencegahan meluas di dalam Masyarakat. Partisipasi dan kesadaran masyarakat sangat dibutuhkan untuk menurunkan jumlah kasus di wilayah Samarinda, khususnya Kelurahan Loa Buah. Kegiatan Bakti Sosial dilakukan kepada masyarakat kelurahan loa buah dan beberapa pedagang. Kegiatan pengabdian ini bertujuan untuk memotivasi masyarakat dalam penggunaan masker dalam kehidupan bermasyarakat. Bakti sosial dilakukan kepada masyarakat kelurahan Loa Buah dengan mensosialisasikan penggunaan masker kain dan kebiasaaan penggunaan masker. Setelah dilakukan bakti sosial dan penggunaan masker maka diharapkan dapat menjadi kebiasaan dalam kehidupan dimasa Pandemi Covid 19.
\end{abstract}

\section{Kata Kunci: Covid 19, Bakti Sosial, Penggunaan Masker}

\begin{abstract}
COVID-19 Pandemic virus in 2020 is a special challenge for all countries and various aspects of life. The increasing number of confirmed cases pays special attention to preparation and widespread prevention within the Society. Community participation and awareness is urgently needed to reduce the number of cases in the Samarinda area, especially Loa Buah Village. Social Service activities were carried out for the people of the Loa Buah sub-district and several traders. This service activity aims to motivate the community to use masks in social life. Social services were carried out to the people of the Loa Buah sub-district by socializing the use of cloth masks and the habit of using masks. After doing social services and using masks, it is hoped that they can become a habit in life during the Covid-19 Pandemic.
\end{abstract}

Key Words: Covid 19, Social Service, Use of Masks

\section{PENDAHULUAN}

Coronavirus (CoV) merupakan virus yang mengakibatkan terjadinya penyakit dengan gejala yang ringan hingga berat. Terdapat dua jenis corona virus yaitu Middle East Respiratory Syndrome (MERS-CoV) dan Severe Acute Respiratory Syndrome (SARS$\mathrm{CoV}$ ), temuan terbaru adalah Novel coronavirus (2019- nCoV). Adanya laporan kasus diawali dengan temuan 
jenis virus baru yag belum pernah diidentifikasi pada manusia (Kementerian Kesehatan RI, 2020).

Penyebaran virus covid 19 pada tahun 2020 menjadi tantangan khusus bagi seluruh Negara dan berbagai aspek kehidupan. Jumlah penderita yang terinfeksi virus covid 19 semakin meningkat. Laporan WHO tanggal 20 Juli menunjukan bahwa terdapat 14.348.858 kasus pada 216 Negara (WHO, 2020). Menurut infogravis covid-19 tanggal 18 Juli 2020 Indonesia menduduki peringkat ke 26 dengan kasus terkonfirmasi sejumlah 84.882 yang tersebar pada 34 Provinsi dan 464 Kabupaten di Indonesia. Data Infografis Covid-19 Samarinda tanggal 20 Juli menunjukan bahwa terdapat 169 kasus terkonfirmasi.

Peningkatan jumlah kasus yang terkofirmasi memberikan perhatian khusus bagi persiapan dan pencegahan meluas di dalam Masyarakat. Masyarakat di Kelurahan Loa Buah telah memasuki tahap new normal seperti kota dan komunitas lainnya. Kegiatan sosial, keagamaan, lokasi pekerjaan perlahan telah melanjutkan aktivitas seperti biasanya. Adanya aturan new normal ini membutuhkan persiapan, penyesuaian agar dapat menurunkan penyebaran virus. Kurangnya pengetahuan dan keterampilan masyarakat dalam memasuki fase new normal ini memberikan pengaruh bagi penyebaran virus covid 19.

Partisipasi dan kesadaran masyarakat sangat dibutuhkan untuk menurunkan jumlah kasus di wilayah Samarinda, khususnya Kelurahan Loa Buah. Masyarakat diharapkan dapat menjalankan berbagai kegiatan sesuai dengan protokol kesehatan yang telah ditetapkan. COVID-19 adalah jenis yang baru ditemukan sehingga informasi terkait pencegahannya masih terbatas, akan tetapi fokus utama dari penyebaran virus ini adalah dengan memutus rantai penularan dengan melakukan perlindungan dan proteksi dasar, isolasi dan deteksi dini. Rangkaian kegiatan ini harus dipahami dan dilakukan, dijalankan dengan patuh oleh seluruh aspek lapisan dan jenis masyarakat masyarakat.

Loa Buah adalah salah satu kelurahan di kecamatan Sungai Kunjang, Kota Samarinda, Provinsi Kalimantan Timur, Indonesia. Tipe Masyarakat di kelurahan Loa Buah adalah urban fringe. Kehidupan seharihari sesuai dengan antara lain. Masyarakat hidup dengan karakteristik heterogen dan saling berbaur antar suku, agama dan golongan. Kelurahan loa buah memiliki intansi pendidikan dari tingkat TK, SD, SLTP dan SLTA. Mayoritas penduduka beragama Islam, disusul dengan agama Katolik, Kristen, Hindu dan Budha. Kegiatan sosial di Kelurahan Loa Buah meliputi bakti sosial setiap RT.

Kelurahan Loa Buah memiliki 1 unit puskesmas pembantu dan terdapat dua tempat praktik bidan mandiri serta satu praktik mandiri dokter. Minimnya jumlah fasilitas kesehatan di kelurahan ini memberikan tantangan baru dala bidang kesehatan. Melalui kegiatan pengabdian masyarakat yang merupakan salah satu wujud tridharma perguruan tinggi diharapkan dapat tujuan untuk membantu masyarakat setempat meningkatkan kapasitas dan kemampuan mitra dalam bidang kesehatan.

\section{METODE}

$\begin{array}{ll}\text { Kegiatan } & \text { pengabdian pada } \\ \text { masyarakat } & \text { diawali }\end{array}$ mengumpulkan peserta kegiatan melalaui kerjasama dengan pihak pengurus gereja. Pemberitahuan akan pelaksanaan kegiatan diumumkan di gereja. Kegiatan Bakti Sosial dilakukan kepada masyarakat kelurahan loa buah dan beberapa pedagang. Kegiatan pengabdian ini bertujuan untuk memotivasi masyarakat dalam 
penggunaan masker dalam kehidupan bermasyarakat.

\section{HASIL dan PEMBAHASAN}

Kegiatan Bakti Sosial dilakukan dengan pemberan masker kain keada masyarakat dan pedagang di wilayah loa buah. Pemberian masker kain ini bertujuan untuk memotivasi penggunaan masker kain sebagai upaya pencegahan penularan covid 19. Menurut Arditama \& Lestari (2002) bahwa ketaatan masyarakat didukung oleh ktaatan dan penguatan solidaritas meliputi nilai- nilai kemanusiaan, kebersamaan masayarakat daam berbagai tingkatan dan didukung oleh adanya aturan hukum dan sanki yang berlaku. Pentingnya meningkatkan kesadaran warga untuk taat pada protokol kesehatan menghadapi penyebaran Covid-19 melalui modal sosial yang berupa jaring sosial. Kegiatan bakti sosial lainnya adalah pemberian sabun cuci tangan, cairan desinfektan dan pelatihan membut airan desinfektan. Tim pelaksan memberikan panduan cara mengencerkan caian desinfektan kepada peseta dengan tujuan agar dapat diimplemetasikan secara mandiri di rumah masing-masing dan komunitas. Kegiatan bakti sosial berjalan dengan baik dan berlangsung dari bulan januari sampai dengan April 2021.

Menurut Maharani (2020) bahwa dalam menghadapi pandemi Covid-19 ini masyarakat sebagai bagian dari warga negara yang berkebajikan (civic virtue) maka diwajibkan untuk menjadi individu yang berkarakter disiplin. Penggunaan masker di masa pandemi Covid-19 ini sangat penting untuk melindungi diri sendiri dan orang lain serta diharapkan penggunaan masker menjadi kebiasaan baru (Irfan, Ayu, 2020). Upaya penanggulangan virus penyebab Covid19 ditujukan dengan mematuhi segala protokol kesehatan termasuk penggunaan masker. Banyak faktor yang dapat memengaruhi kepatuhan seseorang menggunakan masker, seperti pengetahuan, motivasi, persepsi, dan keyakinan tentang Covid - 19 ( Lesilolo, Caroline, 2020).

\section{KESIMPULAN DAN SARAN}

Bakti sosial dilakukan kepada masyarakat kelurahan Loa Buah dengan mensosialisasikan penggunaan masker kain dan kebiasaaan penggunaan masker. Setelah dilakukan bakti sosial dan penggunaan masker maka diharapkan dapat menjadi kebiasaan dalam kehidupan dimasa Pandemi Covid 19.

\section{DAFTAR PUSTAKA}

Arditama, E., \& Lestari, P. (2020). Jogo Tonggo: Membangkitkan kesadaran dan ketaatan warga berbasis kearifan lokal pada masa pandemi Covid-19 di Jawa Tengah. Jurnal Pendidikan Kewarganegaraan Undiksha, 8(2), 157-167.

Irfan, Muhammad, Delfriana Ayu A. (2020). Gambaran Penggunaan Masker Di Masa Pandemi Covid19 Pada Masyarakat Kelurahan Cengkeh Turi Kota Binjai Tahun 2020. Jurnal Kesehatan Masyarakat, Vol.6, No.1 Hal.5- 12

Lesilolo, Caroline Virgine Putri. (2020). Pengetahuan Masyarakat Tentang Covid - 19 Berhubungan Dengan Kepatuhan Menggunakan Masker Pada Masa Pandemi Covid -19. Jurnal Penelitian Perawat Profesional, Volume 3 No 3, Hal 557-564, Agustus 2021 , Global Health Science Group

Kementerian Kesehatan RI. (2020).

Pedoman Kesiapsiagaan

Menghadapi Infeksi Novel

Coronavirus (2019-nCoV) 0.

Jakarta. 
Mahardhani, M.KP, A. (2020). Menjadi

Warga Negara yang Baik pada

Masa Pandemi Covid-19:

Persprektif Kenormalan Baru. JPK

(Jurnal Pancasila dan

Kewarganegaraan), 5(2), 65-76.

doi:http://dx.doi.org/10.24269/jpk.v

5.n2.2020.pp65-76

World Health Organization. (2020).

Coronavirus disease 2019

( COVID-19) Sitution Report-32.

2019(February). 